\title{
Difficulties in Emotion Regulation and Attitudes towards Risky Driving in a Group of Pre-Licensed Drivers
}

\author{
Kristina Žardeckaitė-Matulaitienė, Auksė Endriulaitienė, Laura Šeibokaitè, \\ Rasa Markšaitytė, and Justina Slavinskienè \\ Vytautas Magnus University, Department of Psychology, Kaunas, Lithuania
}

\begin{abstract}
Over-representation of novice drivers in motor-vehicle crashes encourages researchers to look for all possible psychological causes which might be targeted in prevention. The present study is aimed to explore the associations between difficulties in emotional regulation and attitudes towards risktaking while driving in a group of pre-licensed drivers. The sample involved 475 driver's licence candidates who completed the self-reported questionnaire with the Difficulties in Emotion Regulation Scale (DERS) and the Scale of Risk-Taking Attitudes to Driving. Structural equation modelling showed that difficulties in emotion regulation were statistically significant predictors of all measured risk-taking attitudes to driving (over speeding, drunk driving, showing off driving skills, violation of traffic rules, joyriding and positive attitude towards traffic flow) for both males and females. These findings add to the gap in the literature and confirm that emotion regulation difficulties might be the important target addressed in early intervention. Increased emotional competence of pre-licensed drivers might contribute to safer driving and improved road safety.
\end{abstract} drivers

Keywords: difficulties in emotion regulation, attitudes towards risky driving, pre-licensed

\section{Introduction}

The World Health Organization (WHO, 2015) highlights that road traffic injuries are the ninth leading cause of death all over the world, especially related to death of young population (aged 15 - 29 years). Previous studies and statistics of road traffic injuries emphasize that human behaviour is considered as mostly contributing

Kristina Žardeckaitė-Matulaitienė, Department of Psychology, Vytautas Magnus University, Jonavos St. 66-328, 44191, Kaunas, Lithuania. E-mail: kristina. zardeckaite-matulaitiene@vdu.lt

Acknowledgement:

This work was supported by the Research Council of Lithuania (Grant No. GER005/2015). 
to the increased crash risk on the road (Lajunen \& Özkan, 2011; US General Accounting Office, 2003). Traffic psychologists implement research on various psychological causes related to risky driving to develop the most relevant intervention measures.

Young/novice drivers require special attention of both scholars and traffic safety practitioners as they are more often inclined to be risky drivers (Ulleberg \& Rundmo, 2002; WHO, 2015). Many antecedents of risky driving in this group are explored, e.g., cognitive characteristics (Brown et al., 2016; Scialfa et al., 2011), personality traits (Berdoulat, Vavassori, \& Munoz Sastre, 2013; Panayiotou, 2015; Scott-Parker, Watson, King, \& Hyde, 2013), lifestyles (e.g., Møller \& Haustein, 2013), motives and emotions (e.g., Atombo, Wu, Zhong, \& Zhang, 2016; Suhr \& Dula, 2017), and lack of driving experience (Borowsky, Shinar, \& Oron-Gilad, 2010). Still, Roman, Poulter, Barker, McKenna, and Rowe (2015) suggest that this group of drivers "represents multiple homogeneous groups of drivers" (p. 61), who have different developmental trajectories of aberrant driver behaviour, which could be detected quite early before their independent driving. Nevertheless, research on drivingrelated issues in the group of pre-licensed drivers is quite scarce, with some exceptions of studies conducted by Scott-Parker et al. (2013), and Begg, Langley, Brookland, Ameratunga, and Gulliver (2014), which focused on personality and health-risk behaviour. The purpose of current study is to explore the associations between pre-licensed drivers' difficulties in emotional regulation and their attitudes towards risk-taking on the road.

Previous literature provides some evidence that driving attitudes are significant predictors of driving behaviour (Rowe, Maughan, Gregory, \& Eley, 2013; Ulleberg $\&$ Rundmo, 2002), and attitude-based approach might be useful in the groups of traffic users that have no independent driving experience, for example, in driving training phase (Mann \& Sullman, 2008). Driving errors, lapses or violations in the period of learning to drive are mostly related to the lack of driving experience, and not always related to later accident involvement (Mayhew, Simpson, \& Pak, 2003). Therefore, this study focuses on the attitudes towards risky driving of pre-licensed drivers as significant predictors of their later risky behaviour on the road. Moreover, we intend to measure attitudes towards distinct types of risky behaviour on the road (e.g., speeding, joyriding, drink-driving) as Ulleberg and Rundmo (2002) recommended. Their recommendation is based on the previous research suggesting that stronger correlation between attitudes and behaviour might be found if the principle of compatibility is followed (see more in Sutton, 1998). Thus, different attitudes towards specific risky behaviours while driving might provide more useful information about pre-licensed drivers' particular driving behaviour in the future.

Earlier studies confirmed that both negative and positive emotions have an impact for the risk perception on the road, risky or safe driving, and information processing which is necessary for the driving performance (Chan \& Sinhal, 2013; Hu, Xie, \& Li, 2013; Jeon, Walker, \& Yim, 2014; Rhodes, Pivik, \& Sutton, 2015). 
Therefore, emotion regulation abilities become of crucial importance in the safe driving context. Emotion regulation is understood as a deliberate or automatic process targeted to regulate individual's emotions, including its components (situation, attention, appraisal and response) and addressed to various levels of regulation (maintain, diminish or increase of emotion expression) (Gross \& Thompson, 2007). While research in this field more often emphasize the importance of emotion expression control, but according to Gratz and Roemer (2004), emotion regulation may be conceptualized as involving more abilities. These might include abilities to understand (experience and differentiate) and monitor full range of emotions, as well as abilities to control impulsive behaviours and to choose the most appropriate emotion regulation strategy (Gratz \& Roemer, 2004). Moreover, Gratz and Roemer (2004) emphasize that the absence or limitations of any or all of these skills describe difficulties in emotion regulation. Thus, it could be declared that particular skills related to emotion regulation problems represent one broader psychological phenomenon of difficulties in emotion regulation.

Several studies revealed that emotion identification difficulties are related to a higher risk of car accidents among adolescents (Cerniglia et al., 2015). Difficulties in impulse control are related to the increase of speeding or use of cell phone while driving in the experienced drivers' group (Nabi et al., 2005), and various forms of risky driving (e.g., drunk driving, speeding, etc.) in adult male drivers' groups (Brown et al., 2016). Trógolo, Melchior, and Medrano (2014) also have found that more difficulties in different emotion regulation abilities were related to various forms of risky driving or specifically to the increase of texting-while-driving in young drivers group (Feldman, Greeson, Renna, \& Robbins-Monteith, 2011). Šeibokaitė, Endriulaitienè, Sullman, Markšaitytè, and Žardeckaitè-Matulaitienė (2017) have found that difficulties with impulse control and difficulties engaging in goal-directed behaviour were related to more frequent self-reported risky driving of Lithuanian drivers. These relations between emotional regulation and behaviour outcomes of risky driving provide the reason to expect similar associations between emotional difficulties and attitudes. For example, Arnau-Sabatés, Sala-Roca, and Jariot-Garcia (2012) have revealed positive relations between lack of emotional abilities and riskier attitudes towards driving in the middle-aged drivers. Still, the literature does not provide a clear answer if these tendencies are established in the group of pre-licensed drivers. Generalising the above stated, the current study is aimed to evaluate relations between difficulties in emotion regulation and attitudes towards risky driving in a group of pre-licensed drivers. The hypothesis (H1) was that more frequent difficulties in emotion regulation are related to riskier attitudes towards driving.

Additionally, previous research show gender differences both in risky driving attitudes (Ulleberg \& Rundmo, 2002) and in emotion regulation (Gratz \& Roemer, 2004; Ritschel, Tone, Schoemann, \& Lim, 2015). Males have more positive attitudes towards various types of risky driving behaviour (e.g., speeding, drink-driving, rule 
violations, etc.) compared to females (Iversen \& Rundmo, 2012), especially in young or novice drivers' groups (Cordellieri et al., 2016). Although females are more likely to use most emotion regulation strategies (Nolen-Hoeksema \& Aldao, 2011), males show less frequent experiences of emotional awareness than females (Gratz \& Roemer, 2004). Scholars provide various theoretical suggestions explaining these differences, but most of them are related to differences in gender socialization and gender roles in particular (Kitayama \& Markus, 1997; Manstead, 1992; Özkan \& Lajunen, 2005; Social Issues Research Centre, 2004; WHO, 2004). Therefore, gender factor will also be considered in this study while testing the hypothesis.

\section{Method}

\section{Participants}

A total of 487 candidates (191 males, 296 females) participated in the study on voluntary basis. Their age ranged from 17 to 58 years $(M=23.98, S D=8.09)$. Female participants were slightly older than males (mean age of females' $M=24.82, S D=$ 8.39, mean age of males $M=22.68, S D=7.43$, Student $t=-2.87, d f=485, p<.01$ ). Seventy one percent $(71 \%)$ of all participants were $\leq 25$ years old; $23.8 \%$ of the respondents had university education, and $76.2 \%$ did not complete tertiary education.

Driver's license candidates were invited to participate in the study using webpage of the state enterprise "Regitra" responsible for drivers' licensing in Lithuania. Using this online platform, participants freely gave informed consent and were asked to fill in the self-report questionnaire at the webpage before they made a reservation time for their driving exam procedure. They were informed about their rights and confidentiality, as well as about the possibility to contact research implementers if needed. Ethical approval for the study was obtained from the Ethics Committee of Psychology at the Department of Psychology, at Vytautas Magnus University in Lithuania.

\section{Measures}

Difficulties in emotion regulation were assessed using a Lithuanian version of the Difficulties in Emotion Regulation Scale (DERS; Gratz \& Roemer, 2004). This 36-item self-report instrument measures difficulties in six regulatory abilities: Lack of emotional awareness (AWARENESS, 6 items, Cronbach alpha .84), Lack of emotional clarity (CLARITY, 5 items, Cronbach alpha .83), Non-acceptance of emotional responses (NONACCEPTANCE, 6 items, Cronbach alpha .86), Difficulties engaging in goal-directed behaviour (GOALS, 5 items, Cronbach alpha .80), Impulse control difficulties (IMPULSE, 6 items, Cronbach alpha .85), and Limited access to emotion regulation strategies (STRATEGIES, 8 items, Cronbach 
alpha .88). Study participants were asked to indicate how often items applied to them using a five-point scale, which ranged from 1 (almost never) to 5 (almost always). The mean values of each subscale were used in the analyses. A higher score on each sub-scale indicated more emotion regulation difficulties. Lithuanian version of this scale was validated recently (Šeibokaitè et al., 2017).

Pre-drivers' attitudes towards risky driving were measured by the Scale of RiskTaking Attitudes to Driving (Ulleberg \& Rundmo, 2002). Originally this scale consisted of 45 items, measuring 11 distinct risk-taking attitudes, but only 6 specific, mostly relevant for the novice drivers' group attitudes towards risky driving were used for the purpose of this study: attitude towards violation of traffic rules (VIOLATIONS, 2 items; e.g. You should always obey laws while driving, Cronbach alpha .80), attitude towards speeding (SPEEDING, 5 items, e.g. If you have good skills, speeding is $O K$, Cronbach alpha .82), attitude towards drinking and driving (DRINKDRIVING, 3 items, e.g. I might get in the car with a driver who has been drinking, Cronbach alpha .65), attitude towards showing off driving skills to others (SHOWINGOFF, 3 items, e.g. Most people like to show off their skills by driving fast, Cronbach alpha .69), attitude towards traffic flow vs. rule obedience (OBEDIENCE, 9 items, e.g. Sometimes it is necessary to bend the rules to keep traffic going, Cronbach alpha .87), and attitude towards joyriding (JOYRIDING, 3 items, e.g. Speeding and excitement belong together when you are driving, Cronbach alpha .62). All items were scored on a five-point Likert scale, ranging from 1 (strongly disagree) to 5 (strongly agree). The higher score on each subscale indicated a higher preference for risk-taking. Authors of the instrument supported the multidimensionality of the scale and did not recommend using it as a general measure (Ulleberg \& Rundmo, 2002).

\section{Statistical Analysis}

Results were analysed with the help of IBM SPSS 16.0 and the AMOS 4.0 Statistical Package. Before the statistical analysis of the data, all variables used in this study were tested for normality. Kolmogorov-Smirnov test showed significant violation from normal distribution for all scales, but skewness and kurtosis statistics fell in the range of minus and plus one, except for the scale "attitudes towards traffic rules' violations". The latter was transformed by using logarithmic transformation to fit normality distribution better. After transformation, skewness and kurtosis of this scale ranged between minus and plus one. The values for skewness and kurtosis between -2 and +2 are considered acceptable in order to prove normal univariate distribution (George \& Mallery, 2010). Therefore, parametric statistics was applied to all variables of the study. Student's $t$-test was used in order to compare the means of difficulties in emotion regulation and risky driving attitudes between males and females. Bonfferoni's correction for multiple testing was used measuring statistically significant gender differences in all twelve measures (statistically significant difference was for $p<.00$ ). Pearson correlations were calculated to examine zero- 
order correlations between the variables. Structural equation modelling was used to explore the path between difficulties in emotion regulation and attitudes, using difficulties in emotion regulation as a latent variable and the attitudes as observed variables. Decision to use difficulties in emotion regulation as a latent variable was based on the Gratz and Roemer's (2004) theoretical assumption that all aspects of emotion regulation difficulties represent one general phenomenon. Empirical data of this study also confirmed this assumption. Similarly, decision to use separate variables of the attitudes was based on suggestions of Ulleberg and Rundmo (2002).

\section{Results}

First, information concerning measured variables' descriptive statistics (means, standard deviations, and inter-correlations) and gender differences are presented (see Table 1 and Table 2).

Table 1

Descriptive Statistics and Gender Differences in Difficulties in Emotion Regulation and Risky Driving Attitudes

\begin{tabular}{lcccc}
\hline Measure & Males' mean $(S D)$ & Females' mean $(S D)$ & \multirow{2}{*}{$t^{a}$} & $p$ \\
\hline Awareness & $N=191$ & $N=296$ & 7.86 & .000 \\
Clarity & $2.68(0.90)$ & $2.08(0.67)$ & .343 \\
Nonacceptance & $2.09(0.84)$ & $2.02(0.79)$ & 0.95 & .343 \\
Goals & $2.37(0.81)$ & $2.50(0.92)$ & -1.56 & .120 \\
Impulse & $2.39(0.86)$ & $2.51(0.87)$ & -1.47 & .144 \\
Strategies & $1.83(0.74)$ & $1.96(0.79)$ & -1.77 & .078 \\
Violations & $2.12(0.80)$ & $2.12(0.79)$ & -0.01 & .991 \\
transformed value) & $0.65(0.27)$ & $0.52(0.23)$ & 5.59 & .000 \\
Speeding & & & & \\
Drinkdriving & $2.45(0.97)$ & $2.03(0.92)$ & 4.82 & .000 \\
Showingoff & $2.01(0.97)$ & $1.74(0.92)$ & 3.16 & .002 \\
Obedience & $3.15(0.92)$ & $3.17(0.98)$ & -0.26 & .798 \\
Joyriding & $2.30(0.81)$ & $1.93(0.78)$ & 5.08 & .000 \\
\hline
\end{tabular}

${ }^{a} t$ statistic comparing male and female means $(d f=485$; except for the attitude towards violation of traffic rules $d f=356.91$; and lack of emotional awareness $d f=322.70$ )

Data showed (see Table 1) that males had more difficulties in emotional awareness compared to females, but no other statistically significant gender differences were found in other difficulties in emotion regulation scales. Male prelicensed drivers also possessed riskier attitudes towards safety than females in almost all scales of attitudes. They had statistically significantly more positive view towards 
traffic rules violations, speeding, drinking and driving, and necessity to maintain the traffic flow even if rules are violated. These results confirm the need to control for gender effects in later hypothesis testing analysis.

Table 2

Zero-Order Correlations among all Measured Variables $(N=487)$

\begin{tabular}{|c|c|c|c|c|c|c|c|c|c|c|c|c|c|}
\hline Measure & 1. & 2. & 3. & 4. & 5. & 6. & 7. & 8. & 9. & 10. & 11. & 12. & 13. \\
\hline$\overline{1 . \text { Age }}$ & $\begin{array}{ll}- & -1 \\
-1\end{array}$ & -.07 & $-.14^{* *}$ & -.01 & -.03 & .01 & -.05 & $-.17^{* *}$ & $-.15^{* *}$ & -.07 & -.01 & $-.16^{* *}$ & -.03 \\
\hline 2. Awareness & & - & $.34^{* *}$ & -.08 & -.08 & $.11^{*}$ & .05 & $.30^{* *}$ & $.09^{*}$ & $.15^{* *}$ & $-.10^{*}$ & .07 & -.02 \\
\hline 3. Clarity & & & - & $.43^{* *}$ & $.45^{* *}$ & $.63^{* *}$ & $.58^{* *}$ & $.28^{* *}$ & $.20^{* *}$ & $.29^{* *}$ & .07 & $.21^{* *}$ & .09 \\
\hline 4. Nonacceptance & & & & - & $.60^{* *}$ & $.59^{* *}$ & $.72^{* *}$ & .01 & $.30^{* *}$ & $.15^{* *}$ & $.24^{* *}$ & $.27^{* *}$ & $.24^{* *}$ \\
\hline 5. Goals & & & & & - & $.70^{* *}$ & $.74^{* *}$ & $.14^{* *}$ & $.25^{* *}$ & $.15^{* *}$ & $.19^{* *}$ & $.28^{* *}$ & $.21^{* *}$ \\
\hline 6. Impulse & & & & & & - & $.76^{* *}$ & $.26^{* *}$ & $.24^{* *}$ & $.26^{* *}$ & $.11^{* *}$ & $.27^{* *}$ & $.17^{* *}$ \\
\hline 7. Strategies & & & & & & & - & $.20^{* * *}$ & $.32^{* *}$ & $.25^{* *}$ & $.22^{* *}$ & $.34^{* *}$ & $.26^{* *}$ \\
\hline $\begin{array}{l}\text { 8. Violations } \\
\text { (transformed values) }\end{array}$ & & & & & & & & $\begin{array}{l}- \\
-\end{array}$ & $.30^{* *}$ & $.33^{* *}$ & $-.15^{* *}$ & $.33^{* *}$ & -.04 \\
\hline 9. Speeding & & & & & & & & & - & $.29^{* *}$ & $.20^{* *}$ & $.75^{* *}$ & $.37^{* *}$ \\
\hline 10. Drinkdriving & & & & & & & & & & - & .02 & $.28^{* *}$ & .06 \\
\hline 11. Showingoff & & & & & & & & & & & - & $.25^{* *}$ & $.48^{* *}$ \\
\hline 12. Obedience & & & & & & & & & & & & $\begin{array}{ll}- \\
-\end{array}$ & $.39^{* *}$ \\
\hline 13. Joyriding & & & & & & & & & & & & & - \\
\hline
\end{tabular}

${ }^{*} p<.05 ;{ }^{* *} p<.01$.

Correlation analysis between age and difficulties in emotion regulation as well as risky driving attitudes (see Table 2) revealed that younger age of pre-licensed drivers was statistically significantly related to riskier attitudes towards traffic rules violations, drunk driving and violation of traffic rules to maintain traffic flow. Also, younger participants had statistically significantly more difficulties in understanding their emotions compared to the older ones. These results suggest that the age of the participants also should be controlled in later analysis.

To test our hypothesis, we first calculated correlations among difficulties in emotion regulation and risky driving attitudes in separate gender groups of prelicensed drivers (see Table 3).

All scales of difficulties in emotion regulation except one (lack of emotion awareness) in male pre-licensed drivers sample have shown statistically significant consistent correlations with almost all risky driving attitudes: the more males were not accepting their emotional responses, had impulse control difficulties or difficulties engaging in goal-directed behaviours, the more they were intended to have riskier attitudes towards various aspects of problematic driving. Similarly, more limited access to emotion regulation strategies was related to all attitudes towards risky driving in males' group. Lack of emotional clarity was also statistically significantly related positively with four out of six attitudes towards risky driving. 
However, lack of emotion awareness was found to be positively related to more expressed acceptance of traffic rules violations but negatively related to more expressed attitudes towards showing off driving skills to others, joyriding and violating traffic rules in order to maintain traffic flow. It should be mentioned that all correlations between risky driving attitudes and difficulties in emotion regulation were medium or weak.

Table 3

Correlation between Difficulties in Emotion Regulations and Risky Driving Attitudes in Male $(N=191)$ and Female $(N=296)$ Pre-Licensed Drivers Group

\begin{tabular}{lccccccc}
\hline & Gender & Awareness & Clarity & Nonacceptance & Goals & Impulse & Strategies \\
\hline Violations & $\mathrm{M}$ & $.37^{* *}$ & $.43^{* *}$ & -.02 & $.17^{*}$ & $.38^{* *}$ & $.17^{*}$ \\
(transformed & $\mathrm{F}$ & $.29^{* *}$ & $.13^{*}$ & -.03 & .11 & $.16^{* *}$ & $.15^{* *}$ \\
value) & & & & & & & \\
\hline Speeding & $\mathrm{M}$ & -.13 & $.15^{*}$ & $.31^{* *}$ & $.29^{* *}$ & $.28^{* *}$ & $.27^{* *}$ \\
& $\mathrm{~F}$ & .01 & $.23^{* *}$ & $.34^{* *}$ & $.28^{* *}$ & $.30^{* *}$ & $.37^{* *}$ \\
\hline Drinkdriving & $\mathrm{M}$ & .06 & $.26^{* *}$ & $.21^{* *}$ & $.18^{*}$ & $.39^{* *}$ & $.38^{* *}$ \\
& $\mathrm{~F}$ & .09 & $.23^{* *}$ & $.13^{*}$ & $.15^{* *}$ & $.20^{* *}$ & $.19^{* *}$ \\
\hline Showingoff & $\mathrm{M}$ & $-.44^{* *}$ & -.05 & $.31^{* *}$ & $.25^{* *}$ & .07 & $.25^{* *}$ \\
& $\mathrm{~F}$ & -.06 & $.15^{* *}$ & $.22^{* *}$ & $.14^{*}$ & $.12^{*}$ & $.22^{* *}$ \\
\hline Obedience & $\mathrm{M}$ & $-.17^{*}$ & $.18^{*}$ & $.31^{* *}$ & $.33^{* *}$ & $.35^{* *}$ & $.28^{* *}$ \\
& $\mathrm{~F}$ & .02 & $.23^{* *}$ & $.29^{* *}$ & $.26^{* *}$ & $.32^{* *}$ & $.38^{* *}$ \\
\hline Joyriding & $\mathrm{M}$ & $-.38^{* *}$ & -.01 & $.28^{* *}$ & $.27^{* *}$ & $.17^{*}$ & $.22^{* *}$ \\
& $\mathrm{~F}$ & .01 & $.16^{* *}$ & $.26^{* *}$ & $.20^{* *}$ & $.18^{* *}$ & $.31^{* *}$ \\
\hline
\end{tabular}

${ }^{*} p<.05 ;{ }^{* *} p<.01$.

Quite similar results were revealed in the female pre-licensed drivers' group. Lack of emotional clarity, impulse control difficulties and limited access to emotional regulation strategies were statistically significantly positively related to all types of attitudes towards risky driving (see Table 3). More expressed nonacceptance of emotions as though as more expressed difficulties engaging in goaldirected behaviours had statistically significant positive associations with five different types of risky driving attitudes, except for the attitude towards traffic rule violations. Emotional awareness was correlated only with more positive attitudes towards violation of traffic rules. As for males, all correlations between these two phenomena were quite weak.

Lastly, further integrated model of relationship between difficulties in emotion regulation and risky driving attitudes was evaluated using structural equation modelling while testing our hypothesis, which helps to control significant intercorrelations among analyzed variables. Difficulties in emotion regulation were introduced as a latent variable to analysis, while gender and all types of attitudes of risky driving were treated as observed ones. Lack of emotional awareness was omitted 
from the model because it had no significant loadings into the latent variable. Age was not included in the final model because it had no significant relations with neither latent nor observed variables. The model demonstrated good fit to observed data: chisquare $=67.241, d f=31, p<.01 ; \mathrm{CFI}=.986 ;$ RMSEA $=.049$. Covariations among difficulties in emotion regulation variables and attitudes of risky driving were evaluated in the model but were deleted from the figure for better clarity of the results.

Scores of five scales compose a latent factor of difficulties in emotion regulation with significant loadings (see Figure 1) and this factor is statistically significantly positively related to all types of attitudes of risky driving: attitude towards speeding, attitude towards drunk driving, attitude towards traffic flow vs. rule obedience, attitude towards showing off driving skills to others, attitude towards violation of traffic rules, and attitude towards joyriding. Still, non-acceptance of emotions is individually statistically significantly negatively related to risky attitudes towards violations of traffic rules and positively to speeding, while lack of clarity of emotions is also individually statistically significantly positively related to risky attitudes towards violations of traffic rules, but difficulties in impulse control are statistically significantly negatively related to a more positive attitude towards showing off driving skills to others. Additionally, gender (being male) is also statistically significantly related to more pronounced all types of attitudes of risky driving, except the attitude towards showing off driving skills to others. Thus, the hypothesis is partly confirmed.

\section{Discussion}

Worldwide statistics and research (Molina, Garcia-Ros, \& Keskinen, 2014; WHO, 2004) suggest that drivers' training might not be efficient in terms of candidates' abilities to understand driving goals and contexts as though as general skills needed for living (e.g., impulse control skills) (see more Molina et al., 2014). Therefore, early interventions targeted at specific groups of future drivers are extremely needed. The aim of the present study was to evaluate the role of difficulties in emotion regulation for the attitudes towards risky driving in a group of prelicensed drivers in Lithuania. It was hypothesized that more difficulties in emotion regulation would be related to more positive attitudes towards risky driving. In general, the results of this study confirmed this assumption. Specifically, pre-licensed drivers who express more difficulties in emotion regulation, including lack of clarity of emotions, inability to accept various emotions, lack of control of their impulses and have limited number of emotion control strategies, are more likely to consider various types of risky behaviour on the road, e.g., joyriding, overspeeding, drink driving, as acceptable. These results are in line with previous research considering significant influence of emotion acceptance and emotion regulation problems for the risky driving attitudes or risky behaviour on the road (Arnau-Sabatés et al., 2012; Brown et al., 2016; Hu et al., 2013; Trógolo et al., 2014). It might be considered that 


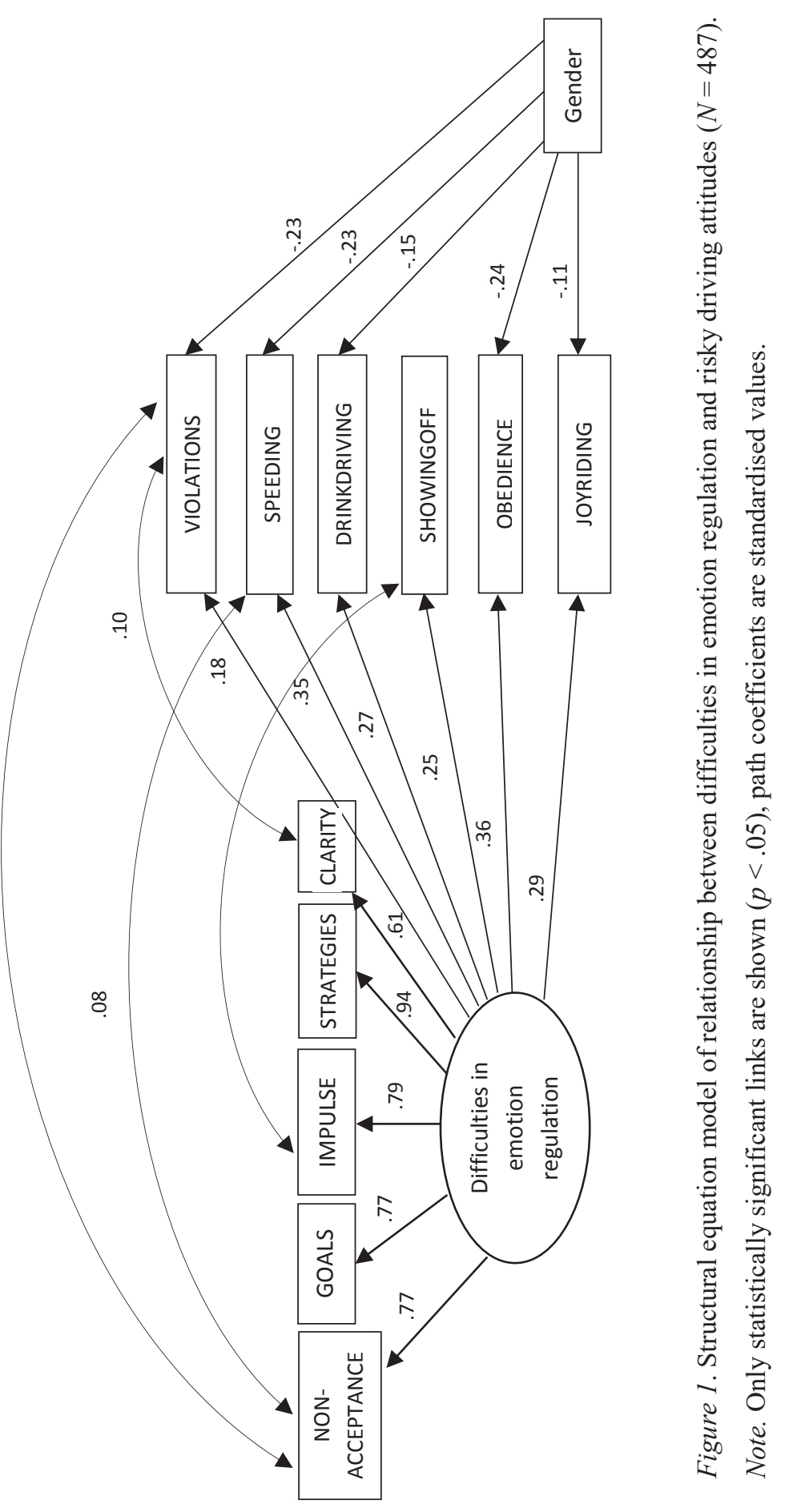


limited emotional abilities do not help drivers to manage stressful situations. As $\mathrm{Hu}$ et al. (2013) declare, inability to accept negative emotions distort drivers' rational judgment of the risk on the road and motivates them to get rid of this unacceptable state with more risky behaviour. Research on neurobiological characteristics of different forms of risky driving might explain these relations more in depth. For example, Brown et al. (2016) have found that dysfunctions in the medial prefrontal region are related to the inability to follow the rules. They also stated that positive evaluation of speeding is related to acquirement of enough dopamine release by involving in stimulation by taking risks as a mean to diminish feelings of prolonged dysphoria. Similarly, Nabi et al. (2005) also found that drivers' impatience, one of the emotion regulation problems, is related to their engagement in particular risky behaviour on the road (e.g., speeding or use of cellular phone). On the other hand, driving can be understood as emotional engagement activity (see Redshaw, 2004). Specifically, some drivers, especially young males, involve in risky driving in order to experience elevated levels of strong positive emotions. As Redshaw (2004) suggest, exceeding speed limits for some of the drivers might be a way to experience enjoyment. So, difficulties in management of positive emotions also contribute to higher rates of risky behaviour on the road.

It was also found that specific difficulties in emotion regulation (e.g., nonacceptance of emotions, impulse control problems or emotional clarity) were uniquely related to specific attitudes towards risky driving (e.g., drinking and driving or driving to show off, positive attitude towards traffic rules violations) in the prelicensed drivers' group and some of these relations were not in the same direction as our general findings. The more pre-licensed driver was able to accept his or her emotions, the more he or she expressed positive attitude towards traffic violations. Similarly, the less impulse control difficulties person possessed, the more positively he or she valued speeding. However, higher non-acceptance of emotions was also related to more positive evaluation of speeding while driving, as though as more expressed lack of emotional clarity was related positively to higher acceptance of traffic rules violations. These findings represent how different forms of emotion regulation co-occur in specific contexts, different levels of awareness and goals for using specific emotion regulation strategy (Gross \& Thompson, 2007; Gyuruk, Gross, \& Etkin, 2011). Some of the relations between emotion regulation and attitudes might be more related to overconfidence in person's ability to control their own actions (e.g., the more I think that I can control my impulses, the more I feel confident in showing off while driving for others). Other relations reflect compensatory functions of emotion regulation for the aberrant behaviour (e.g., I can't accept my negative mood, or I don't understand what is happening to me, so I engage in less safe activities [speeding] to elevate my condition or to forget). Relationship between emotion overregulation process and engagement in various forms of aggressive behaviour were suggested and confirmed by other scholars (e.g., Roberton, Daffern, \& Bucks, 2014). However, it must be also noted that research on relations between pre-licensed drivers' emotion regulation difficulties and attitudes 
towards risky driving are quite rare, thus replication of this research in other samples should be implemented before making overall generalizations.

Current study suggests that addressing the most important psychological issues in driving training programs or early intervention campaigns might be an effective way to prevent the subsequent independent risky driving after licensing. Some previous studies confirmed that interventions based on relaxation techniques are useful in reducing road rage or aggression of the drivers (e.g., Deffenbacher, 2009). Similarly, 'insight' training programs (focused on attitudinal-motivational skills) also showed some effectiveness (Senserrick \& Swinburne, 2001). Future research is needed to measure the efficacy of such interventions.

In the end some gender-related results should be also mentioned. As it was expected, gender differences in the attitudes towards risky driving were found in this group of pre-licensed drivers, with males having more positive attitudes towards almost all aspects of the risky driving compared to females (no gender differences were found in their attitudes towards showing off while driving and joyriding). These results are in line with large number of the research in various groups of the drivers all over the world (e.g., Akaateba \& Amoh-Gyimah, 2013; González-Iglesias, Gómez Fraguela, \& Luengo-Martín, 2012; Social Issues Research Centre, 2004) and could be explained by gender role differences and importance of social norms. It is stated that males are more prone to demonstrating their masculinity by engaging in various risky activities, including risky driving; they are also more inclined to not follow the rules of the society (Akaateba \& Amoh-Gyimah, 2013; Özkan \& Lajunen, 2006). Further analysis showed that only one gender-related difference in emotion regulation difficulties was found. Specifically, males were less aware of their emotions than females. These results confirm previous studies in this field, suggesting that gender-related emotion regulation issues might be important for these differences (Gratz \& Roemer, 2004; McRae, Ochsner, Mauss, Gabrieli, \& Gross, 2008).

Some methodological limitations of the present study should be enclosed, too. First, even though we tried to invite all drivers' licence candidates to participate in this study via invitation letters sent to all driving schools in Lithuania, and the sample size is sufficient, it is possible that particular people decided to take part in this study (e.g., those who possess sufficient self-reflection abilities or are interested in traffic safety promotion). Thus, our results could not be generalized to all population of prelicensed drivers. Replication of this study with more representative sample from general population may allow for more generalized results. Secondly, it must be admitted that the gap between attitude and behaviour is still relevant in psychology research, even though traffic psychology research has shown that drivers' self-reports and actual driving are significantly correlated (Lajunen \& Summala, 2003; Parker, Mastead, Stradling, Reason, \& Baxter, 1992). In support of this, Mirzaei et al. (2014), and $\mathrm{Hu}$ et al. (2013) confirm, that attitudes towards risky driving are closely related to the driving behaviour. However, longitudinal research on future drivers' pre- 
licence attitudes towards risky driving and their actual post-licence driving behaviour may add significant contribution to this methodological limitation of the study. Third, DERS is used to measure difficulties in regulation of negative emotions, but prior studies have shown that risky driving could be related to positive emotions also (Mesken, Hagenzieker, Rothengatter, \& de Ward 2007). Thus, evaluation of the relations between regulation of positive emotions and risky driving attitudes as well as risky driving behaviour should be considered in future research. Furthermore, we must admit that several scales measuring difficulties in emotion regulation in this study had marginal reliabilities. Thus, use of other scales related to emotion regulation might be valuable to replicate results of this study. Next, additional psychological features of pre-licensed driver (e.g., personality traits or general mental ability) might also be important predictors both of their attitudes towards risky driving and actual risky driving in the future. Finally, cross-sectional design of this study does not provide the possibility to measure causal effects between the difficulties in emotion regulation and attitudes towards risky driving. To solve this problem, longitudinal studies that can evaluate importance of emotion regulation difficulties in pre-driving period for the risky driving after obtaining drivers' licence should be encouraged. Evaluation of longitudinal changes in the attitudes towards risky driving through the driving training process might also be valuable.

The present study confirms previous statements on emotion regulation impact for the risky driving and expands our knowledge about the importance of these relations in early stages of driving behaviour. Consistent with previous results from other groups of drivers (Arnau-Sabatés et al., 2012; Trógolo et al., 2014), this study suggests that difficulties in emotion regulation including emotion understanding and behavioural reactions are significantly related to many types of risky driving attitudes of pre-licensed drivers. Although, results show that all pre-licensed drivers possessing more difficulties in emotion regulation are more prone to value positively different types of risky behaviour on the road. Results from this study may help to identify and implement better means for managing traffic safety.

\section{References}

Akaateba, A. M., \& Amoh-Gyimah, R. (2013). Driver attitude towards traffic safety violations and risk taking behaviour in Kumasi: The gender and age dimension. International Journal for Traffic and Transport Engineering, 3, 479-494.

Arnau-Sabatés, L., Sala-Roca, J., \& Jariot-Garcia, M. (2012). Emotional abilities as predictors of risky driving behaviour among a cohort of middle aged drivers. Accident Analysis \& Prevention, 45, 818-825. https://doi.org/10.1016/j.aap.2011.07.021

Atombo, C., Wu, C., Zhong, M., \& Zhang, H. (2016). Investigating the motivational factors influencing drivers' intentions to unsafe driving behaviours: Speeding and overtaking violations. Transportation Research Part F: Traffic Psychology \& Behaviour, 43, 104121. https://doi.org/10.1016/j.trf.2016.09.029 
Begg, D. J., Langley J. D., Brookland, R. L., Ameratunga, S., \& Gulliver, P. (2014). Prelicensed driving experience and car crash involvement during the learner and restricted, licence stages of graduated driver licensing: Findings from the New Zealand Drivers Study. Accident Analysis \& Prevention, 62, 153-160. https://doi.org/10.1016/j.aap. 2013.08.027

Berdoulat, E., Vavassori, D., \& Munoz Sastre, M. T. (2013). Driving anger, emotional and instrumental aggressiveness, and impulsiveness in the prediction of aggressive and transgressive driving. Accident Analysis \& Prevention, 50, 758-767. https://doi.org/10. 1016/j.aap.2012.06.029

Borowsky, A., Shinar, D., \& Oron-Gilad, T. (2010). Age, skill, and hazard perception in driving. Accident Analysis \& Prevention, 42, 1240-1249. https://doi.org/10.1016/j.aap. 2010.02.001

Brown, T. G., Ouimet, M. C., Eldeb, M., Tremblay, J., Vingilis, E., Nadeau, L., Pruessner, J., \& Bechara, A. (2016). Personality, executive control, and neurobiological characteristics associated with different forms of risky driving. PLoS ONE, 11(2), e0150227. https://doi.org/10.1371/journal.pone.0150227

Cerniglia, L., Cimino, S., Ballarotto, G., Casini, E., Ferrari, A., Carbone, P., \& Cersosimo, M. (2015). Motor vehicle accidents and adolescents: An empirical study on their emotional and behavioral profiles, defense strategies and parental support. Transportation Research Part F: Traffic Psychology \& Behaviour, 35, 28-36. https://doi.org/10.1016/ j.trf.2015.09.002

Chan, M., \& Singhal, A. (2013). The emotional side of cognitive distraction: Implications for road safety. Accident Analysis \& Prevention, 50, 147-154. https://doi.org/10.1016/j. aap.2012.04.004

Cordellieri, P., Baralla, F., Ferlazzo, F., Sgalla, R., Piccardi, L., \& Giannini, A. M. (2016). Gender effects in young road users on road safety attitudes, behaviors and risk perception. Frontiers in Psychology, 7. https://doi.org/10.3389/fpsyg.2016.01412

Deffenbacher, J. (2009). Angry drivers: Characteristics and clinical interventions. Revista Mexicana de Psicologia, 26, 5-16.

Feldman, G., Greeson, J., Renna, M., \& Robbins-Monteith, K. (2011). Mindfulness predicts less texting while driving among young adults: Examining attention-and-emotionregulation motives as potential mediators. Personality and Individual Differences, 51(7), 856-861. https://doi.org/10.1016/j.paid.2011.07.020

George, D., \& Mallery, M. (2010). SPSS for Windows step by step: A simple guide and reference. Boston: Pearson.

González-Iglesias, B., Gómez Fraguela, X. A., \& Luengo-Martín, A. (2012). Driving anger and traffic violations: Gender differences. Transportation Research Part F: Traffic Psychology \& Behaviour, 15(4), 404-412. 
Gratz, K. L., \& Roemer, L. (2004). Multidimensional assessment of emotion regulation and dysregulation: Development, factor structure, and initial validation of the difficulties in emotion regulation scale. Journal of Psychopathology and Behavioral Assessment, 26(1), 41-54. http://dx.doi.org/10.1007/s10862-008-9102-4

Gross, J. J., \& Thompson, R. (2007). Emotion regulation. Conceptual foundations. In J. J. Gross (Ed.), Handbook of emotion regulation (pp. 3-26). New York: Guilford Press.

Gyuruk, A., Gross, J. J. \& Etkin, A. (2011). Explicit and implicit emotion regulation: A dualprocess framework. Cognition and Emotion, 25(3), 400-412. https://doi.org/10.1080/ 02699931.2010 .544160

Hu, T. Y., Xie, X., \& Li, J. (2013). Negative or positive? The effect of emotion and mood on risky driving. Transportation Research Part F: Traffic Psychology \& Behaviour, 16, 29-40. https://doi.org/10.1016/j.trf.2012.08.009

Iversen, H. H., \& Rundmo, T. (2012). Changes in Norwegian drivers' attitudes towards traffic safety and driver behaviour from 2000 to 2008. Transportation Research Part F: Traffic Psychology \& Behaviour, 15, 95-100. https://doi.org/10.1016/j.trf.2011.12.006

Jeon, M., Walker, B. N., \& Yim, J. B. (2014). Effects of specific emotions on subjective judgment, driving performance, and perceived workload. Transportation Research Part F: Traffic Psychology \& Behaviour, 24, 197-209. https://doi.org/10.1016/j.trf.2014. 04.003

Kitayama, S., \& Markus, H. R. (1997). Emotion and culture: Empirical studies of mutual influence. Washington, DC: American Psychological Association.

Lajunen, T., \& Özkan, T. (2011). Self-report instruments and methods. In E. Porter (Ed.), Handbook of traffic psychology (pp. 43-59). London, UK: Elsevier Inc.

Lajunen, T., \& Summala, H. (2003). Can we trust self-reports of driving? Effects of impression management on driver behaviour questionnaire responses. Transport Research Part F: Traffic Psychology \& Behaviour, 6, 97-107. https://doi.org/10.1016/ S1369-8478(03)00008-1

Mann, H. N., \& Sullman, M. J. M. (2008). Pre-driving attitudes and non-driving road-user behaviours: Does the past predict future driving behaviour? In L. Dorn (Ed.), Driver behaviour and training (Vol. 3, pp. 65-73). Aldershot, UK: Ashgate.

Manstead, A. S. R. (1992). Gender differences in emotion. In A. Gale \& M. W. Eysenck (Eds.), Handbook of individual differences: Biological perspectives (pp. 355-387). Chichester, England: Wiley.

Mayhew, D. R., Simpson, H. M., \& Pak, A. (2003). Changes in collision rates among novice drivers during the first months of driving. Accident Analysis \& Prevention, 35(5), 683691. https://doi.org/10.1016/S0001-4575(02)00047-7

McRae, K., Ochsner, K. N., Mauss, I. B., Gabrieli, J. J., \& Gross, J. J. (2008). Gender differences in emotion regulation: An fMRI study of cognitive reappraisal. Group Processes \& Intergroup Relations, 11(2), 143-162. https://doi.org/10.1177/ 1368430207088035 
Mesken, J., Hagenzieker, M. P., Rothengatter, T., \& de Ward, D. (2007). Frequency, determinants, and consequences of different drivers' emotions: An on-the-road study using self-reports, (observed) behaviour, and physiology. Transportation Research Part F: Traffic Psychology \& Behaviour, 10, 458-475. https://doi.org/10.1016/j.trf.2007. 05.001

Mirzaei, R., Hafezi-Nejad, N., Sadegh Sabagh, M., Ansari Moghaddam, A., Eslami, V., Rakhshani, F., \& Rahimi-Movaghar, V. (2014). Dominant role of drivers' attitude in prevention of road traffic crashes: A study on knowledge, attitude, and practice of drivers in Iran. Accident Analysis and Prevention, 66, 36-42.

Molina, J. G., Garcia-Ros, R., \& Keskinen, E. (2014). Implementation of the driver training curriculum in Spain: As analysis based on the Goals for Driver Education (GDE) framework. Transportation Research Part F: Traffic Psychology \& Behaviour, 26, 2837. https://doi.org/10.1016/j.trf.2014.06.005

Møller, M., \& Haustein, S. (2013). Keep on cruising: Changes in lifestyle and driving style among male drivers between the age of 18 and 23. Transportation Research Part F: Traffic Psychology \& Behaviour, 20, 59-69. https://doi.org/10.1016/j.trf.2013.05.003

Nabi, H., Consoli, S. M., Chastang, J.-F., Chiron, M., Lafont, S., \& Lagarde, E. (2005). Type A behavior pattern, risky driving behaviors, and serious road traffic accidents: A prospective study of the GAZEL cohort. American Journal of Epidemiology, 161(9), 864-870.

Nolen-Hoeksema, S., \& Aldao, A. (2011). Gender and age differences in emotion regulation strategies and their relationship to depressive symptoms. Personality and Individual Differences, 51(6), 704-708. https://doi.org/10.1016/j.paid.2011.06.012

Özkan, T., \& Lajunen, T. (2005). Why are there sex differences in risky driving? The relationship between sex and gender-role on aggressive driving, traffic offences, and accident involvement among young Turkish drivers. Aggressive Behavior, 31, 547-558.

Özkan, T., \& Lajunen, T. (2006). What causes the differences in driving between young men and women? The effects of gender roles and sex on young driver's driving behavior and self-assessment. Transportation Research Part F: Traffic Psychology \& Behaviour, 9, 269-277.

Panayiotou, G. (2015). The bold and the fearless among us: Elevated psychopathic traits and levels of anxiety and fear are associated with specific aberrant driving behaviors. Accident Analysis \& Prevention, 79, 117-125. https://doi.org/10.1016/j.aap.2015.03. 007

Parker, D., Manstead, A. S. R., Stradling, S. G., Reason, J. T., \& Baxter, J. S. (1992). Intention to commit driving violations: An application of the Theory of Planned Behavior. Journal of Applied Psychology, 77(1), 94-101. http://dx.doi.org/10.1037/0021-9010. 77.1 .94

Redshaw, S. (2004). Theories of driver behaviour and driving emotions. In Safer roads, people, vehicles: Road Safety Research, Policing and Education Conference, 14 to 16 November 2004, Burswood International Resort, Casino Convention Centre, Perth, Western Australia (pp. 1-9). Perth: Road Safety Research, Policing and Education Conference. 
Žardeckaitè-Matulaitienė, K., Endriulaitienè, A., Šeibokaitè, L., Markšaitytè, R., Slavinskienė, J.: Emotion Regulation and Attitudes of Pre-licensed Drivers

Ritschel, L. A., Tone, E. B., Schoemann, A. M., \& Lim, N. E. (2015). Psychometric properties of the difficulties in emotion regulation scale across demographic groups. Psychological Assessment, 27(3), 944-954. http://dx.doi.org/10.1037/pas0000099

Rhodes, N., Pivik, K., \& Sutton, M. (2015). Risky driving among young male drivers: The effects of mood and passengers. Transportation Research Part F: Traffic Psychology \& Behaviour, 28, 65-76. https://doi.org/10.1016/j.trf.2014.11.005

Roberton, T., Daffern, M., \& Bucks, R. S. (2014). Beyond anger control: Difficulty attending to emotions also predicts aggression in offenders. Psychology of Violence, 5(1), 74-83. http://dx.doi.org/10.1037/a0037214

Roman, G. D., Poulter, D., Barker, E., McKenna, F. P., \& Rowe, R. (2015). Novice drivers' individual trajectories of driver behavior over the first three years of driving. Accident Analysis \& Prevention, 82, 61-69. https://doi.org/10.1016/j.aap.2015.05.012

Rowe, R., Maughan, B., Gregory, A. M., \& Eley, T. C. (2013). The development of risky attitudes from pre-driving to fully-qualified driving. Injury Prevention, 19(4), 244-249. http://dx.doi.org/10.1136/injuryprev-2012-040551

Scialfa, C. T., Deschenes, M. C., Ference, J., Boone, J., Horswill, M. S., \& Wetton, M. (2011). A hazard perception test for novice drivers. Accident Analysis \& Prevention, 43, 204208. https://doi.org/10.1016/j.aap.2010.08.010

Scott-Parker, B., Watson, B., King, M. J., \& Hyde, M. K. (2013). A further exploration of sensation seeking propensity, reward sensitivity, depression, anxiety, and the risky behaviour of young novice drivers in a structural equation model. Accident Analysis \& Prevention, 50, 465-471. https://doi.org/10.1016/j.aap.2012.05.027

Šeibokaitè, L., Endriulaitienè, A., Sullman, M. J., Markšaitytė, R., \& ŽardeckaitèMatulaitienè, K. (2017). Difficulties in emotion regulation and risky driving among Lithuanian drivers. Traffic Injury Prevention, 18, 688-693. https://doi.org/10.1080/ 15389588.2017.1315109

Senserrick, T. M., \& Swinburne, G. C. (2001). Evaluation of an Insight Driver-Training Program for Young Drivers. Report no. 186. Monash University: Accident Research Centre.

Social Issues Research Centre. (2004). Sex differences in driving and insurance risk. Oxford: UK.

Suhr, K. A., \& Dula, C. S. (2017). The dangers of rumination on the road: Predictors of risky driving. Accident Analysis \& Prevention, 98, 153-160. https://doi.org/10.1016/j.aap. 2016.10.026

Sutton, S. (1998). Predicting and explaining intentions and behaviour: How well are we doing? Journal of Applied Social Psychology, 28, 1317-1338. https://doi.org/10.1111/j. 1559-1816.1998.tb01679.x

Trógolo, M. A., Melchior, F., \& Medrano, L. A. (2014). The role of difficulties in emotion regulation on driving behavior. Journal of Behavior, Health \& Social Issues, 6(1), $107-$ 117. https://doi.org/10.5460/jbhsi.v6.1.47607 
Ulleberg, P., \& Rundmo, T. (2002). Risk-taking attitudes among young drivers: The psychometric qualities and dimensionality of an instrument to measure young drivers' risk-taking attitudes. Scandinavian Journal of Psychology, 43(3), 227-237. https://doi.org/10.1111/1467-9450.00291

US General Accounting Office. (2003). Factors contributing to traffic crashes and NHTSA's efforts to address them. Statement of Peter Guerrero, Director, Physical Infrastructure Issues. Washington, DC: US General Accounting Office.

World Health Organization. (2004). Preventing road traffic injury: A public health perspective for Europe. Geneva: WHO.

World Health Organization. (2015). Global status report on road safety 2015. Geneva: WHO.

\title{
Emocionalna stabilnost i odnos prema rizičnoj vožnji kod vozača početnika
}

\begin{abstract}
Sažetak
Velik postotak vozača početnika u prometnim nezgodama potakla je istraživače na ispitivanje mogućih psihičkih uzroka, na koje bi se moglo djelovati u sklopu preventivnih programa. Cilj je ovog istraživanja bio ispitati povezanost poteškoća u emocionalnoj regulaciji i stavova prema rizičnoj vožnji kod pristupnika vozačkom ispitu, odnosno osoba koje još nemaju vozačku dozvolu. U uzorak je uključeno 475 pristupnika vozačkom ispitu muškoga i ženskoga spola, koji su ispunili Upitnik poteškoća u regulaciji emocija (DERS) i Skalu rizičnih stavova o vožnji. Prema rezultatima strukturalnog modeliranja teškoće u emocionalnoj regulaciji značajan su prediktor svih mjerenih stavova o vožnji koja ometa ili ugrožava druge sudionike u prometu (prebrza vožnja, vožnja u pijanom stanju, kršenje prometnih pravila, obijesna vožnja i sl.). Ovi nalazi dopunjuju dosadašnja istraživanja i potvrđuju važnost rane intervencije teškoća u emocionalnoj regulaciji. Viša emocionalna kompetencija kandidata za vozački ispit može pridonijeti sigurnijoj vožnji i većoj sigurnosti na cesti.
\end{abstract}

Ključne riječi: teškoće u emocionalnoj regulaciji, stavovi o rizičnoj vožnji, vozači početnici

Primljeno: 29.8.2018. 